\title{
Up-regulation of adrenomedullin receptor gene expression in activated local stem cells during rat adrenal regeneration
}

\author{
PIERA REBUFFAT ${ }^{1}$, CARLO MACCHI $^{1}$, LUDWIK K. MALENDOWICZ $^{2}$ and GASTONE G. NUSSDORFER ${ }^{1}$ \\ ${ }^{1}$ Department of Human Anatomy and Physiology, University of Padua, I-35121 Padua, Italy; \\ ${ }^{2}$ Department of Histology and Embryology, Poznan School of Medicine, PL-60781 Poznan, Poland
}

Received July 27, 2007; Accepted September 11, 2007

\begin{abstract}
Previous studies showed that adrenomedullin (AM) gene expression was up-regulated in the regenerating rat adrenal cortex after enucleation and contra-lateral adrenalectomy, the effect being significant at day 1 after surgery and peaking between days 3 and 7 . Using the same experimental model, we investigated by real time-polymerase chain reaction the mRNA expression of the AM receptor components: calcitonin receptor-like receptor (CRLR) and receptor activity-modifying proteins (RAMP)2 and 3. At time 0 (60 min after enucleation; control group), the CRLR mRNA content was $\sim 2$ - and 5-fold higher than that of RAMP2 and $\mathrm{RAMP}_{3}$, respectively. No significant changes in CRLR mRNA expression were observed in relation to the time elapsed from enucleation. RAMP 2 and $\mathrm{RAMP}_{3}$ mRNAs did not exhibit significant changes at day 1 after surgery, but underwent a marked increase between days 3 and 7 . The mRNA content of the two RAMPs decreased at days 14 and 28 , although remaining significantly higher than that of the controls. These findings indicate that the AM receptor subtypes AM1-R (CRLR-RAMP2) and AM2-R (CRLR$\mathrm{RAMP}_{3}$ ) are up-regulated in enucleated adrenals, and the hypothesis is advanced that this effect depends on the increased local production of AM. The concerted increase in $\mathrm{AM}$ and its receptor expression would greatly improve the autocrine-paracrine mechanism(s) by which AM favors proliferation of zona glomerulosa stem cells during adrenal regeneration.
\end{abstract}

\section{Introduction}

Many lines of evidence suggest localization of adrenocortical stem cells in the zona glomerulosa (ZG), either adherent to the connective capsule or at the border with the zona

Correspondence to: Professor G.G. Nussdorfer, Department of Human Anatomy and Physiology, Section of Anatomy, University of Padua, Via Gabelli 65, I-35121 Padua, Italy

E-mail: gastone.nusdorfer@unipd.it

Key words: adrenomedullin, adrenomedullin receptors, gene expression, adrenal regeneration, rat fasciculata, the so called zona intermedia $(1,2)$. Under normal conditions, the renewal rate of adrenocortical cells is very low, so that it is conceivable that most stem cells are dormant. A useful experimental model of rapid adrenocortical growth, and consequently of strong activation of local stem cells, is rat adrenal regeneration after enucleation (3-5). Recent studies demonstrated that adrenomedullin (AM) gene expression is up-regulated in the adrenal parenchyma during the early stages of regeneration $(6,7)$.

$\mathrm{AM}$ is a multi-functional regulatory peptide, that acts via a calcitonin receptor-like receptor (CRLR). CRLR selectivity for AM depends on its interaction with the members of a family of receptor activity-modifying proteins (RAMPs): $\mathrm{RAMP}_{1}$ generates calcitonin gene-related peptide receptors, while $\mathrm{RAMP}_{2}$ and $\mathrm{RAMP}_{3}$ give rise to two AM receptors, referred to as $\mathrm{AM} 1-\mathrm{R}$ and $\mathrm{AM} 2-\mathrm{R}(8,9)$. AM and its receptors are expressed in the mammalian $\mathrm{ZG}$, and $\mathrm{AM}$ has been shown to stimulate proliferation of ZG cells (10-13). Hence, it is conceivable that the increased production of AM in adrenal tissue after enucleation may favor the gland's regeneration.

Obviously, this effect of AM would be more intense if AM gene overexpression were coupled to that of its receptor genes, but earlier studies did not examine this possibility $(6,7)$. It, therefore, seemed worthwhile to investigate by semiquantitative real time-reverse transcription (RT)polymerase chain reaction (PCR) the expression of CRLR, $\mathrm{RAMP}_{2}$ and $\mathrm{RAMP}_{3}$ mRNAs at the early, middle and late stages of adrenal regeneration.

\section{Materials and methods}

Experimental design. Adult male Sprague-Dawley rats (200$300 \mathrm{~g}$ body weight) were obtained from Charles-River (Como, Italy), and the experimental protocol was approved by the local Ethics Committee for Biomedical Studies. Under ether anesthesia, the left adrenal glands of 28 rats were enucleated and the contra-lateral glands were removed. Surgery was carried out by dorsal approach without opening the peritoneum (6). Enucleation consisted of an incision to the adrenal capsule, and extrusion and complete removal of adrenal parenchyma; only ZG cells adherent to the capsule (bona fide adrenocortical stem cells) remained in situ. Rats were given an intramuscular injection of amplital (20 mg/100 g) immediately after surgery and maintained on a standard diet and $0.9 \%$ $\mathrm{NaCl}$ saline to drink. They were decapitated at day 0 (60 min 


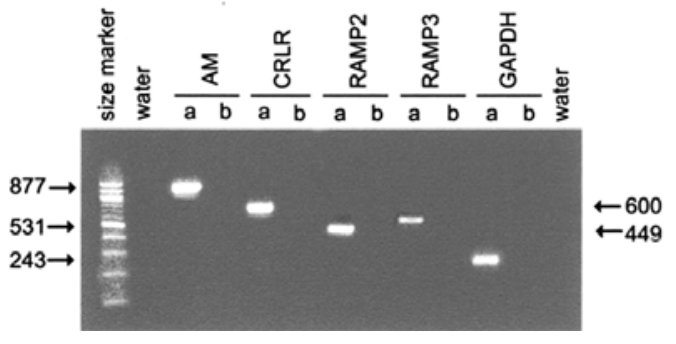

Figure 1. Ethidium bromide-stained 2\% agarose gel showing cDNA amplified with rat AM, CRLR, RAMP2, RAMP3 and GAPDH-specific primers from RNA of an exemplary control rat regenerating adrenal cortex. Primer sequences were as follows: pAM sense-418-5', 5'-ACTCAGAGCA CAGCCCAGAT-3' and pAM antisense-1249-3', 5'-AAGTTGTAGAGGAT GGGGTTG-3' (877 bp); CRLR sense-609-5', 5'-CTGGGACGGATGGCT ATG-3' and CRLR antisense-1208-3', 5'-CAGGCAGGAAGCAGAGGA-3' (600 bp); RAMP2 sense-104-5', 5'-GCTGTTACTGCTGCTGTTGC-3' and RAMP2 antisense-552-3', 5'-CATCGCCGTCTTTACTCCTC-3' (449 bp); RAMP3 sense-78-5', 5'-CTGCTTTGTGGTGAGTGTGC-3' and RAMP3 antisense-608-3', 5'-TCAGGAGGACTTTGACACGA-3' (531 bp); and GAPDH sense-83-5', 5'-GGGCTGCCTTCTCTTGTGAC-3' and GAPDH antisense-325-3', 5'-CGCCAGTAGACTCCACGACA-3' (243 bp). First lanes were loaded with $200 \mathrm{ng}$ of a size marker (Marker VIII; Boehringer, Mannheim, Germany). No amplification of PCR mixture without prior RT of RNA is shown as negative control.

after enucleation, control group), 1, 3, 5, 7, 14 and 28 after surgery ( 4 animals for each time point), and their regenerating adrenals were promptly removed, frozen and stored at $-80^{\circ} \mathrm{C}$.

$R T-P C R$. Total RNA was extracted from regenerating adrenal cortexes, and reverse transcribed to cDNA (14-16). Conventional PCR was carried out as previously described $(17,18)$, using the following program: a predenaturation step at $95^{\circ} \mathrm{C}$ for $8 \mathrm{~min}$ to activate Taq DNA polyerase, followed by 35 cycles of denaturation at $95^{\circ} \mathrm{C}$ for $60 \mathrm{sec}$, annealing at $60^{\circ} \mathrm{C}$ for $45 \mathrm{sec}$ and extension at $72^{\circ} \mathrm{C}$ for $90 \mathrm{sec}$. Primer sequences and the predicted sizes of amplicons are indicated in the legend of Fig. 1. To rule out the possibility of amplifying genomic DNA, one PCR was performed without prior RT of the RNA. Detection of the PCR amplification products was carried out by size fractionation on $2 \%$ agarose gel electrophoresis. The specificity of the PCR was verified by sequencing analysis (19).

Real time-PCR. Semiquantitative real time-PCR was carried out as previously detailed (20-23) in a Bio-Rad I-Cycler iQ Detection system (Bio-Rad Laboratories, Milan, Italy). Briefly, reactions were performed in $25 \mu \mathrm{l}$ of final volume solution containing $200 \mathrm{mM}$ specific primers (Fig. 1 legend), 12.5 $\mu 1$ iQ SYBR-Green Supermix (Bio-Rad Laboratories) and $2 \mu \mathrm{l}$ of RT-reaction solution. The PCR program consisted of a denaturation step at $95^{\circ} \mathrm{C}$ for $3 \mathrm{~min}, 35$ cycles of two amplification steps $\left(95^{\circ} \mathrm{C}\right.$ for $15 \mathrm{sec}$ and $60^{\circ} \mathrm{C}$ for $\left.30 \mathrm{sec}\right)$ and melting curve at $60-90^{\circ} \mathrm{C}$ with a heating rate of $0.5^{\circ} \mathrm{C} / 10 \mathrm{sec}$. The specificity of amplification was tested at the end of each run by real time-melting analysis, using the I-Cycler iQ Sofware 3.0. All samples were amplified in duplicate, and glyceraldehyde-3-phosphate dehydrogenase (GAPDH) was used as a housekeeping gene; its mRNA expression equated to 1 .
Statistics. The results were expressed as the means \pm SEM $(n=4)$, and the statistical significance of differences among experimental groups was estimated using ANOVA, followed by the Duncan's multiple range test.

\section{Results}

Conventional RT-PCR detected the expression of AM, CRLR, RAMP2 and RAMP 3 mRNAs in the control regenerating adrenal cortex (time 0) (Fig. 1). Real time-PCR showed that at time 0 , the CRLR, RAMP2 and RAMP 3 mRNA/GAPDH mRNA ratios were $\sim 1,0.5$ and 0.2 , respectively (Fig. 2). No significant changes were found in the CRLR mRNA expression in the regenerating adrenal parenchyma in relation to the time elapsed from enucleation (Fig. 2A). Conversely, both RAMP2 and RAMP3 mRNAs displayed marked increases between day 3 and day 7 after surgery ( 22- and 9-fold, respectively). The expression of $\mathrm{RAMP}_{2}$, but not RAMP3, was still above the control value at day 14 , and at day 28 the mRNA of both RAMPs was not different from the controls (Fig. 2B and C).

\section{Discussion}

Previous studies have shown that the activation of local stem cells during the early differentiative (from day 0 to day 3 ) and proliferative stages (from day 4 to day 7) of enucleationinduced adrenal regeneration is coupled to a marked increase in AM expression as mRNA and protein (7). The hypothesis has been advanced that relative hypoxia, ensuing from the disruption of the adrenal vascular bed, and the local increased release of inflammatory cytokines, caused by surgical adrenal manipulation, may be involved in this response. The marked increase in the blood concentration of ACTH due to the drop in glucocorticoid secretion following enucleation and contra-lateral adrenalectomy does not seem to play a major role, because up-regulation of AM gene expression also occurs in regenerating adrenals of rats where contra-lateral adrenal was spared and the level of circulating ACTH was in the normal range.

The possibility that hypoxia and inflammatory cytokines may induce up-regulation of AM receptor expression appears to be unlikely. In fact, the rise in RAMP2 and RAMP3 expression occurred only at day 3 from enucleation, while a marked increase in the AM gene transcription and translation was observed as early as $24 \mathrm{~h}$ post surgery (7). This sizeable temporal delay strongly suggests that up-regulation of $R_{A M P}$ and $R_{A M P}$, and consequently of $A_{1}-R$ and $A M_{2}-R$, depends on the increased local production of AM. According to this view, findings are available showing that under various pathological and experimental conditions a strict positive correlation exists between AM and RAMP2/3 expression in cardiomyocytes (24-27). Moreover, recent evidence showed that AM $\left(10^{-8} \mathrm{M}\right)$ enhanced AM1-R expression in cultured immortalized human microvascular endothelial cells (28).

However, there are many relevant differences between these last findings and our present ones, probably connected to the different tissues and experimental models employed. In the human endothelial cells cultured in vitro the response to 
A

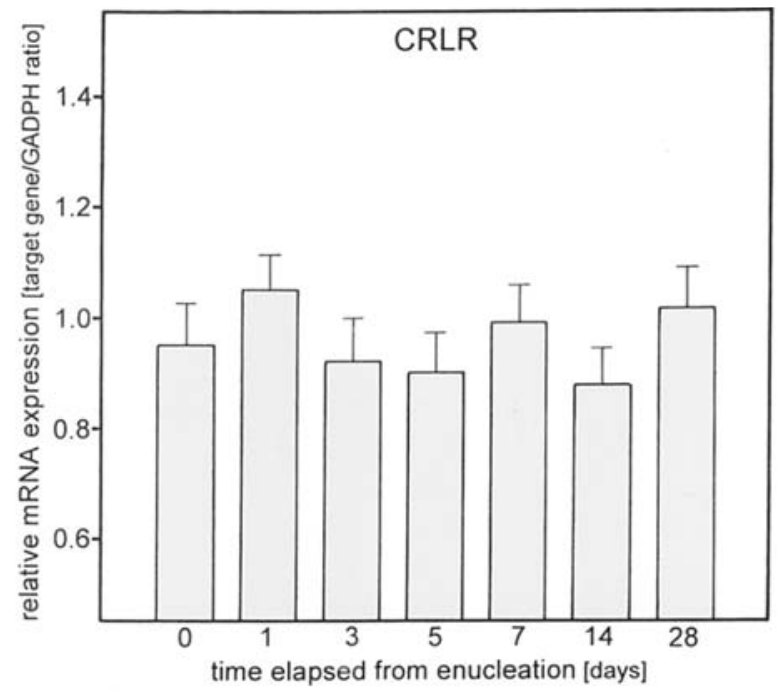

B

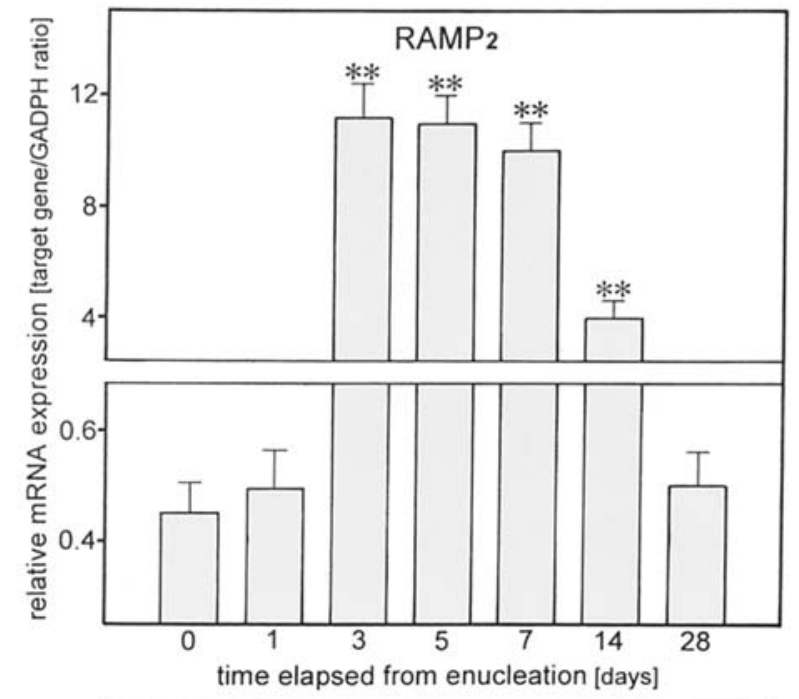

C

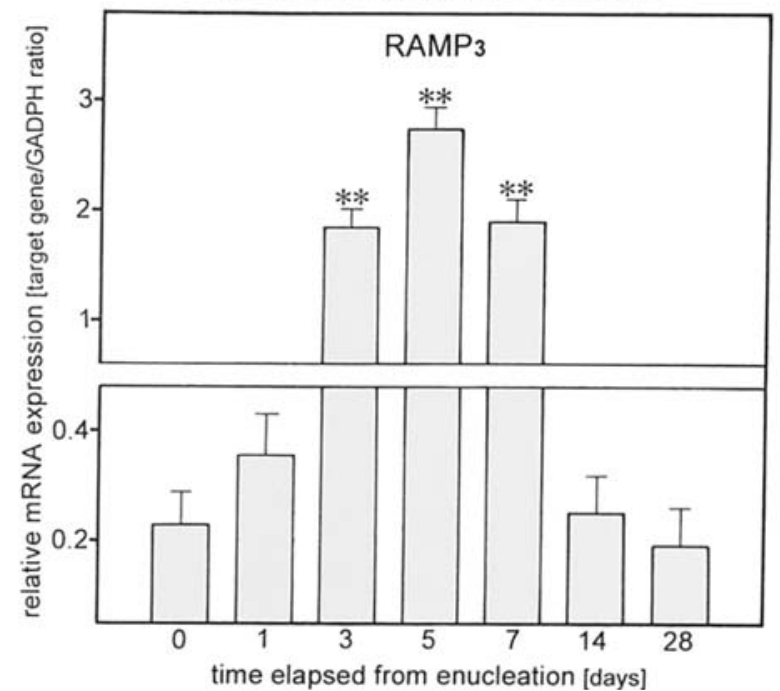

Figure 2. Semiquantitative real time-PCR assay of CRLR (A), RAMP2 (B) and $\mathrm{RAMP}_{3}(\mathrm{C})$ mRNA expression in regenerating rat adrenal cortex in relation to the time elapsed from enucleation and contra-lateral adrenalectomy. Bars are the means $\pm \operatorname{SEM}(n=4) .{ }^{* *} \mathrm{P}<0.01$ compared to the controls (time 0 ).

the addition of elevated concentrations of AM was biphasic, peaking at 1 and $24 \mathrm{~h}$, while in the regenerating adrenal cortex the response became manifest at $72 \mathrm{~h}$, because it conceivably ensued from the up-regulated translation of AM. $\mathrm{AM}$ increased the mRNA expression of RAMP2, but not $\mathrm{RAMP}_{3}$ in endothelial cells, while in the regenerating adrenal tissue the expression of both RAMPs was increased. It is possible that differences in the basal level of expression of the two RAMPs may account for this discrepancy. RAMP 3 mRNA expression was found to be very low or absent in human umbilical vein endothelial cells (29; Albertin and Nussdorfer, unpublished data), but significant in rat and human ZG cells $(11,12)$; hence, it seems legitimate to hypothesize that human endothelial cells are provided with functional AM1-R only, and ZG cells with both AM1-R and AM2-R. Finally, AM enhanced CRLR expression in endothelial cells, while up-regulation of CRLR transcription was not observed in regenerating adrenal tissue. It could be tentatively suggested that basal CRLR protein content in ZG cells, but not in endothelial cells, may be sufficiently elevated to face up-regulation of transcription/translation of $\mathrm{RAMP}_{2}$ and $\mathrm{RAMP}_{3}$ genes in giving rise to functional AM receptors. Accordingly, at time 0 the CRLR mRNA content of ZG stem cells was 2- and 5-fold higher than that of $\mathrm{RAMP}_{2}$ and $\mathrm{RAMP} 3$, respectively.

Be that as it may, our present findings are in keeping with the view that AM up-regulates the expression of its own receptors; the concerted increase in AM production and AM receptor expression would greatly improve the autocrineparacrine mechanism(s) by which this peptide favors proliferation of adrenocortical stem cells during gland regeneration. Obviously, optimal regeneration requires enhanced neovascularization to restore a normal vascular bed, and the up-regulation of the AM system may favor this process, because abundant evidence demonstrates the strong pro-angiogenic action of this peptide (30-33).

\section{References}

1. Nussdorfer GG: Cytophysiology of the adrenal cortex. Int Rev Cytol 98: 1-405 1986.

2. Mitani F, Mukai K, Miyamoto H, Suematsu M and Ishimura Y: The undifferentiated cell zone is a stem cell zone in adult rat adrenal cortex. Biochim Biophys Acta 1619: 317-324, 2003.

3. Dallman MF: Control of adrenocortical growth in vivo. Endocr Res 10: 213-242, 1984.

4. Taki TM and Nickerson PA: Differentiation and proliferation of adrenocortical cells during early stages of regeneration. Lab Invest 53: 91-100, 1985.

5. Engeland WC and Levay-Young BK: Changes in the glomerulosa cell phenotype during adrenal regeneration in rats. Am J Physiol 276: R1374-R1382, 1999

6. Albertin G, Rucinski M, Carraro G, Forneris M, Andreis PG, Malendowicz LK and Nussdorfer GG: Adrenomedullin and vascular endothelium growth factor genes are overexpressed in the regenerating rat adrenal cortex, and AM and VEGF reciprocally enhance their mRNA expression in cultured rat adrenocortical cells. Int J Mol Med 16: 431-435, 2005.

7. Rebuffat P, Macchi C, Malendowicz LK and Nussdorfer GG: Up-regulation of adrenomedullin gene expression in the regenerating rat adrenal cortex. Int J Mol Med 20: 551-555, 2007.

8. Lopez J and Martinez A: Cell and molecular biology of the multifunctional peptide adrenomedullin. Int Rev Cytol 221: 1-92, 2002.

9. Poyner DR, Sexton PM, Marshal I, Smith DM, Quirion R, Born W, Muff R, Fisher JA and Foord SM: International union of pharmacology. XXXII. The mammalian calcitonin generelated peptides, adrenomedullin, amylin and calcitonin receptors. Pharmacol Rev 54: 233-246, 2002. 
10. Nussdorfer GG: Proadrenomedullin-derived peptides in the paracrine control of the hypothalamo-pituitary-adrenal axis. Int Rev Cytol 206: 249-284, 2001.

11. Andreis PG, Albertin G, Conconi MT, Carraro G, Malendowicz LK, Ziolkowska A and Nussdorfer GG: Evidence for an autocrineparacrine role of adrenomedullin in the cultured rat adrenal zona glomerulosa cells. Int J Mol Med 10: 401-405, 2002.

12. Rebuffat P, Forneris ML, Aragona F, Ziolkowska A, Malendowicz LK and Nussdorfer GG: Adrenomedullin and its receptors are expressed in the zona glomerulosa of human adrenal gland: Evidence that ADM enhances proliferation and decreases apoptosis in cultured ZG cells. Int J Mol Med 9: 119-124, 2002.

13. Malendowicz LK, Conconi MT, Parnigotto PP and Nussdorfer GG: Endogenous adrenomedullin system regulates the growth of rat adrenocortical cells cultured in vitro. Regul Pept 112: 27-31, 2003.

14. Albertin G, Carraro G and Nussdorfer GG: Human adrenomedullin gene silencing by short interfering RNAs: A preliminary study. Int J Mol Med 15: 579-583, 2005.

15. Andreis PG, Rucinski M, Neri G, Conconi MT, Petrelli L, Parnigotto PP, Malendowicz LK and Nussdorfer GG: Neuropeptides $\mathrm{B}$ and $\mathrm{W}$ enhance the growth of human adrenocortical carcinoma-derived NCl-H295 cells by exerting MAPK p42/p44mediated proliferogenic and antiapoptotic effects. Int $\mathrm{J}$ Mol Med 16: 1021-1028, 2005.

16. Rucinski M, Andreis PG, Ziolkowska A, Nussdorfer GG and Malendowicz LK: Differential expression and function of beacon in the rat adrenal cortex and medulla. Int J Mol Med 16: 35-40, 2005.

17. Albertin G, Carraro G, Petrelli L, Guidolin D, Neri G and Nussdorfer GG: Endothelin-1 and adrenomedullin enhance the growth of human adrenocortical carcinoma-derived SW-13 cell line by stimulating proliferation and inhibiting apoptosis. Int J Mol Med 15: 469-474, 2005.

18. Rucinski M, Albertin G, Spinazzi R, Ziolkowska A, Nussdorfer GG and Malendowicz LK: Cerebellin in the rat adrenal gland: Gene expression and effects of CER and [des-Ser1]CER on the secretion and growth of cultured adrenocortical cells. Int J Mol Med 15: 411-415, 2005

19. Rossi GP, Sticchi D, Giuliani L, Bernante P, Zavattero S, Pessina AC and Nussdorfer GG: Adiponectin receptor expression in the human adrenal cortex and aldosterone-producing adenomas. Int J Mol Med 17: 975-980, 2006.

20. Carraro G, Albertin G, Aragona F, Forneris M, Casale V, Spinazzi R and Nussdorfer GG: Age-dependent decrease in the ghrelin gene expression in the human adrenal cortex: A real time PCR study. Int J Mol Med 17: 319-321, 2006.

21. Rucinski M, Ziolkowska A, Hochól A, Pucher A, Macchi C, Belloni AS, Nussdorfer GG and Malendowicz LK: Estradiol and resveratrol stimulating effect on osteocalcin, but not osteonectin and collagen- $1 \alpha$ gene expression in primary culture of rat calvarial osteoblast-like cells. Int J Mol Med 18: 565-570, 2006.
22. Ziolkowska A, Rucinski M, Tyczewska M, Belloni AS, Nowak M, Nussdorfer GG and Malendowicz LK: Down-regulation of the beacon gene expression in the regenerating rat adrenal cortex. Peptides 27: 3216-3219, 2006.

23. Ziolkowska A, Tortorella C, Nussdorfer GG, Rucinski M, Majchrzak $M$ and Malendowicz LK: Accumulation of steroidogenic acute regulatory protein mRNA and decrease in the secretory and proliferative activity of rat adrenocortical cells in the presence of proteasome inhibitors. Int J Mol Med 17: 865-868, 2006.

24. Øie E, Vinge LE, Andersen GØ, Yndestad A, Krobert KA, Sanderg C, Ahmed MS, Haug T, Levy FO, Skomedal T and Attramadal H: RAMP2 and RAMP3 mRNA levels are increased in failing rat cardiomyocytes and associated with increased responsiveness to adrenomedullin. J Mol Cell Cardiol 38: 145-151, 2005.

25. Pan CS, Jiang W, Zhong GZ, Zhao J, Pang YZ, Tang CS and Qi YF: Hypertension induced nitric oxide synthase inhibitor increases responsiveness of ventricular myocardium and aorta of rat tissue to adrenomedullin stimulation in vitro. Life Sci 78: 398-405, 2005.

26. Bell D, Zhao YY, Kelso EJ, McHenry EM, Rush LM, Lamont VM, Nicholls DP and McDermott BJ: Up-regulation of adrenomedullin and its receptor components during cardiomyocyte hypertrophy induced by chronic inhibition of nitric oxide synthesis in rats. Am J Physiol 290: H904-H914, 2006.

27. Pan CS, Jiang W, Wu SY, Zhao J, Pang YZ, Tang CS and Qi YF: Potentiated response to adrenomedullin in myocardia and aortas in spontaneously hypertensive rat. Basic Res Cardiol 101: 193-203, 2006.

28. Schwarz N, Renshaw D, Kapas S and Hinson JP: Adrenomedullin increases the expression of calcitonin-like receptor and receptor activity modifying protein 2 mRNA in human microvascular endothelial cells. J Endocrinol 190: 505-514, 2006.

29. Albertin G, Ruggero M, Guidolin D and Nussdorfer GG: Gene silencing of human RAMP2 mediated by short-interfering RNA. Int J Mol Med 18: 531-535, 2006.

30. Nagaya N, Mori H, Mukotami S, Kangawa K and Kitamura S: Adrenomedullin: angiogenesis and gene therapy. Am J Physiol 288: R1432-R1437, 2005.

31. Ribatti D, Nico B, Spinazzi R, Vacca A and Nussdorfer GG: The role of adrenomedullin in angiogenesis. Peptides 26: 1670-1675, 2005.

32. Nikitenko LL, Fox SB, Kekoe S, Rees MCP and Bicknell R: Adrenomedullin and tumor angiogenesis. Br J Cancer 94: 1-7, 2006.

33. Ribatti D, Conconi MT and Nussdorfer GG: Non-classical endogenous regulators of angiogenesis. Pharmacol Rev 59: 185205, 2007. 